Original article

\title{
Growth and cell cycle regulation by isoflavones in human breast carcinoma cells
}

\author{
Chingwen YING $^{\mathrm{a} *}$, Jih-Tay Hsu ${ }^{\mathrm{b}}$, Hsiao-Chiao $\mathrm{HuNG}^{\mathrm{a}}$, \\ Don-Hei LIN ${ }^{\mathrm{a}}$, Long-Fang Oliver $\mathrm{CHEN}^{\mathrm{c}}$, Lu-Kai WANG ${ }^{\mathrm{a}}$ \\ ${ }^{\text {a }}$ Department of Microbiology, Soochow University, Taipei, Taiwan, Republic of China \\ ${ }^{b}$ Department of Animal Science, National Taiwan University, Taipei, Taiwan, Republic of China \\ ${ }^{c}$ Institute of Botany, Academia Sinica, Taipei, Taiwan, Republic of China
}

(Received 7 June 2001; accepted 25 January 2002)

\begin{abstract}
The isoflavones daidzein and biochanin A induced a biphasic growth response in T-47D human breast cancer cells. At growth stimulatory concentrations, daidzein increased the percentage of cells entering the $\mathrm{S}$ phase, while at a growth inhibitory concentration, daidzein obstructed the progression of the cell cycle in the G2/M phase. Biochanin A regulated the cell cycle progression in a similar manner and showed a delay in the progression from the $\mathrm{S}$ phase to the G2/M phase at growth inhibitory concentrations. The levels of a cell cycle regulatory protein, P53, in response to the treatment of isoflavones, were also determined. Cells that became de-attached and floated in the medium after treatment with growth inhibitory concentrations of daidzein or biochanin A, showed higher P53 levels than cells that remained attached. These results suggest that daidzein and biochanin A influence T-47D cell proliferation and cell cycle progression, and that the underlying mechanisms might be associated with the P53 protein levels.
\end{abstract}

isoflavones / cell cycle / P53 / breast cancer cells

\section{INTRODUCTION}

Isoflavones are a group of chemicals present in plants and foliage. The structural similarity of isoflavones to natural animal estrogens has suggested that this group of chemicals may exhibit certain estrogen- or antiestrogen-like activities [20,21]. In recent years, isoflavones have attracted much attention because of their possible cancer-preventing effects for certain cancers. It has been observed that Asian women who consume a traditional low-fat high-soy diet have a lower risk of developing breast cancer,

* Correspondence and reprints

E-mail: cying@mail.scu.edu.tw 
estrogen deficiency diseases (heart disease and osteoporosis), and menopausal symptoms than women living in the industrialized Western world [26]. Such marked differences between women of Asian and Western cultures are not due to genetic factors but are more likely dietary or environmental in origin [42].

It has been suggested that isoflavones influence carcinogenesis via their estrogenic and antiestrogenic actions. The estrogenic effects of isoflavones include binding to the estrogen receptor (ER) or the type II estradiol (E2)-binding site [18, 19], promotion of proliferation of reproductive organs in animals [39], induction of $\mathrm{pS} 2$ protein expression [29] and stimulation of growth in estrogen-dependent human breast cancer cells $[12,13,37]$. Suggested antiestrogenic effects include competition with E2 for binding to the ER [34], reduction of estrogen synthesis via the inhibition of aromatase activity [1], down-regulation of E2-induced expression of ER and the $\mathrm{pS} 2$ protein in MCF-7 cells [14, 38], and inhibition of E2-induced growth in breast cancer cells $[12,13,25]$. The factors determining whether estrogenic or antiestrogenic effects of isoflavones predominate are quite complex. These factors may be species- and tissue-specific and appear to include the type of the compound, concentration and length of time used, and the method of administration.

Little is known about the actual exposure to isoflavones by humans who consume phytoestrogen-rich foods. Although some reports have indicated that serum levels of genistein may be as high as $18.5 \mu \mathrm{M}$ [23], the levels in human serum have never been reported to exceed $10 \mu \mathrm{M}$ after consumption of dietary soybean products $[3$, 23]. Adlercreutz et al. [2] reported the plasma concentration of genistein was only $276 \mathrm{nM}$ in Japanese men consuming a lowfat diet with high content of soy products [4]. The results of in vitro studies suggest that at these concentrations, stimulation, rather than inhibition may be the primary effect of isoflavones on cell growth $[12,38]$.

The purpose of this study was to analyze the effects of the isoflavones, daidzein and biochanin A, on the mechanisms of cell proliferation and cell cycle progression, especially at growth stimulatory and growth inhibitory concentrations. A human breast cancer cell line T-47D that is responsive to estrogen [18, 27, 31, 35] was used in this study. The isoflavone daidzein has been found in substantial concentrations ( $5 \%$ dry mass or less) in two major pasture legumes Trifolium subterraneum (subterranean clover), and T. pratense (red clover) as well as in soybeans (up to $100-300 \mathrm{mg} \cdot 100 \mathrm{~g}^{-1}$ ) [6]. Biochanin $\mathrm{A}$ is the precursor of genistein that has been suggested to be one of the major biologically active isoflavones in human breast cancer cell lines [5, 6]. The impacts of isoflavones on a cell cycle regulatory protein P53 were also determined in T-47D cells at both growth inhibitory and stimulatory concentrations.

\section{MATERIALS AND METHODS}

\subsection{Chemicals}

Biochanin A and daidzein were purchased from Sigma Chemical Co. (St. Louis, MO, USA) and Research Biochemicals International (Natick, MA, USA), respectively. Phenol red-free Dulbecco modified Eagle medium (DMEM), Hank balanced salt solution (HBSS), fetal bovine serum (FBS), and the antibiotic/antimycotic mix were purchased from GIBCO BRL (Gaithersburg, MD, USA). Solutions of biochanin A and daidzein were prepared in dimethylsulphoxide (DMSO) and stored at $-20{ }^{\circ} \mathrm{C}$ in the dark.

\subsection{Cell culture conditions}

T-47D cells were grown in RPMI 1640 containing $1 \mathrm{X}$ antibiotic/antimycotic mix, 
$5 \mathrm{mM}$ N-(2-hydroxy-ethyl)piperazine-N'2-ethanesulfonic acid, and $0.37 \%$ sodium bicarbonate supplemented with $10 \%$ fetal bovine serum (FBS). Cultures were maintained at $37{ }^{\circ} \mathrm{C}$ in a humidified atmosphere of $95 \%$ air $/ 5 \% \mathrm{CO}_{2}$ and fed every $2 \mathrm{~d}$.

\subsection{Proliferation assays}

Cells were cultured in a medium supplemented with $10 \%$ FBS until confluency was reached and then they were cultured in a serum-free medium for another $24 \mathrm{~h}$. After the cell density was determined by the trypan blue dye exclusion assay $[10,11,28]$, the cells were seeded in a medium containing $10 \%$ dextran/charcoal stripped FBS at the density of $1.5 \times 106$ per T25 flask or 104 cells per well for 96 -well culture plates. The trypan blue dye exclusion assay was used to determine the number of viable cells since viable cells that exclude the trypan blue dye remain transparent while non-viable cells appear to be blue under the microscope. The medium was removed following a $24 \mathrm{~h}$ preculture period to ensure attachment; fresh medium supplemented with $10 \%$ dextran/ charcoal stripped FBS alone or with daidzein $\left(0.25\right.$ to $\left.100 \mu \mathrm{g} \cdot \mathrm{mL}^{-1}\right)$ or biochanin A (1 or $\left.20 \mu \mathrm{g} \cdot \mathrm{mL}^{-1}\right)$ was then added. DMSO was added to $0.1 \%(\mathrm{v} / \mathrm{v})$ in parallel cultures as a control. Following an incubation period (0-4 days) at $37^{\circ} \mathrm{C}$, the number of viable cells was quantified by the trypan blue dye exclusion assay for cells grown in culture flasks or by the WST-1 cell proliferation kit according to the manusfactor's instruction (Boehringer Mannheim Biochemicals, Mannheim, Germany) for cells grown in 96-well culture plates. The WST-1 proliferation kit is based on the fact that the tetrazolium salt WST-1 is cleaved to form the formazan dye by the mitochondrial succinate-tetrazolium reductase system, which is active only in viable cells. Therefore, the number of metabolically active cells in the culture can be determined from the amount of the formazan dye formed. The formation of the formazan dye leads to an increase in the absorbance at the wavelength of $420 \mathrm{~nm}$ and can be measured using a scanning multiwell spectro-photometer (ELISA reader). The difference between the absorbance at $420 \mathrm{~nm}$ and the absorbance at $650 \mathrm{~nm}$ that represents the background, can be directly used as an index of the numbers of viable cells in each well.

\subsection{Cell cycle analysis}

Cells treated with biochanin A or daidzein were collected, washed twice with PBS and resuspended in a phosphate-buffered $\mathrm{NaCl}$ solution $(\mathrm{PBS})$ to $1 \times 10^{6} \cdot \mathrm{mL}^{-1}$ in the presence of $50 \mu \mathrm{g} \cdot \mathrm{mL}^{-1}$ propidium iodide, $0.1 \%$ sodium citrate and $0.1 \%$ Triton $\mathrm{X}-100$ $[7,8]$. The cells were incubated overnight at $4{ }^{\circ} \mathrm{C}$ in the dark before being subjected to flow cytometry (Epics Elite ESP XL, Coulter). Each analysis was repeated at least twice.

\subsection{Immunoprecipitation and immunoblotting}

T-47D cells were incubated with daidzein $\left(5,40\right.$ or $\left.80 \mu \mathrm{g} \cdot \mathrm{mL}^{-1}\right)$ or biochanin $\mathrm{A}(1,20$ or $40 \mu \mathrm{g} \cdot \mathrm{mL}^{-1}$ ) for $48 \mathrm{~h}$ and cell lysates were individually prepared from cells that remained attached to the culture flasks and from those floating in the culture medium. Cell lysates were prepared according to the procedures described previously [41]. Protein concentration was determined by BCA assays (BioRad), and the presence of equal amounts of protein in each sample was confirmed by fractionation of the cellular proteins via an SDS-PAGE and Coomassie blue staining. Cell lysates of $200 \mu \mathrm{L}$ containing equal concentrations of protein were immunoprecipitated at $4{ }^{\circ} \mathrm{C}$ with $10 \mu \mathrm{L}$ of anti-P53 antibody. The mouse monoclonal anti-P53 antibody (clone Ab-6) whose epitope is within residues 2-25 of human P53 recognizes both human wild-type and mutant P53 (Calbiochem, CA, USA). Following 
gentle agitation overnight, $50 \mu \mathrm{L}$ of protein $\mathrm{A}$ agarose were added, and the reaction mixture was incubated for $12 \mathrm{~h}$ at $4{ }^{\circ} \mathrm{C}$. The reaction mixture was then centrifuged and washed three times with ice-cold dilution buffer $(0.1 \%$ Triton X-100, 20 mM Tris$\mathrm{HCl}, 0.14 \mathrm{M} \mathrm{NaCl}$ ), and with TSA buffer (20 mM Tris- $\mathrm{HCl}, 0.14 \mathrm{M} \mathrm{NaCl}$ ) and $0.005 \mathrm{M}$ Tris- $\mathrm{HCl}$ ( $\mathrm{pH}$ 6.8) once each at $4{ }^{\circ} \mathrm{C}$. The resulting precipitated immune complexes were solubilized at $100{ }^{\circ} \mathrm{C}$ for 3-5 min in $20 \mu \mathrm{L}$ of Laemmli sample buffer.

The solubilized proteins were separated by SDS-PAGE and transferred to a nitrocellulose membrane by electroblotting. The P53 proteins present in the immune complexes in each sample were detected using the anti-P53 antibody followed by alkaline phosphatase-conjugated goat anti-rabbit IgG antibodies and an enhanced chemiluminescence (ECL) western blotting system (Amersham, Uppsala, Sweden).

\subsection{Statistic analysis}

Statistical analysis was performed by analysis of variance with the General Linear Model. When the F-test was significant $(p<0.05)$, differences among treatment means were tested by Least Squares Means with significant level set at $p<0.05$.

\section{RESULTS}

\subsection{Cell growth regulation of daidzein and biochanin $\mathrm{A}$ in T-47D cells}

The effects of daidzein and biochanin A on the cell proliferation of T-47D cells are shown in Figure 1. A biphasic response was observed in T-47D cells treated with each isoflavone: at a concentration of $5 \mu \mathrm{g} \cdot \mathrm{mL}^{-1}$ of daidzein, the cell growth was enhanced $150 \%$ whereas growth was inhibited by $54 \%$ at a concentration of $40 \mu \mathrm{g} \cdot \mathrm{mL}^{-1}$ (Figs. 1A and 1B). Biochanin A exhibited a growth stimulatory effect of $136 \%$ of the control at
$1 \mu \mathrm{g} \cdot \mathrm{mL}^{-1}$ and a growth inhibitory effect of $40 \%$ at $20 \mu \mathrm{g} \cdot \mathrm{mL}^{-1}$ (Fig. 1C). This biphasic effect of daidzein and biochanin $\mathrm{A}$ is in good agreement with the observations made in previous studies $[12,13]$.

\subsection{Cell cycle progression of daidzein- and biochanin A-treated T-47D cells}

At $40 \mu \mathrm{g} \cdot \mathrm{mL}^{-1}$ of daidzein, the cell growth of T-47D was inhibited and the cell cycle was blocked in the $\mathrm{G} 2 / \mathrm{M}$ phase (Fig. 2A, Tab. I). The percentage of cells in G2/M was 35.7 and 34.2 at 24 and 48 h respectively, compared to 23.5 and 25.3 in the corresponding controls. At $5 \mu \mathrm{g} \cdot \mathrm{mL}^{-1}$ of daidzein, the percentage of T-47D cells in the $\mathrm{S}$ phase was greatly increased from $6.5 \%$ in the corresponding control cells to $42.7 \%$ at $48 \mathrm{~h}$. This might account for the growth stimulation observed in T-47D cells treated with $5 \mathrm{mg} \cdot \mathrm{mL}^{-1}$ of daidzein.

Biochanin A showed a similar effect on the cell cycle in T-47D cells (Fig. 2B). The cell cycle in $\mathrm{T}-47 \mathrm{D}$ cells treated with $20 \mu \mathrm{g} \cdot \mathrm{mL}^{-1}$ of biochanin A was blocked at the $\mathrm{G} 2 / \mathrm{M}$ phase. At $24 \mathrm{~h}$ and $48 \mathrm{~h}$, the percentage of cells reentering the G1 phase from G2/M was only $77 \%$ and $79 \%$, respectively, of that of the corresponding DMSO-treated control cells at $24 \mathrm{~h}$ and $48 \mathrm{~h}$. At a concentration of $1 \mu \mathrm{g} \cdot \mathrm{mL}^{-1}$, biochanin A was found to stimulate cell growth and to increase the percentage of cells in the $S$ phase. At $48 \mathrm{~h}$, the percentage of biochanin A-treated cells in the $S$ phase was 7.97 fold higher than in the cells treated DMSO in parallel with DMSO.

\subsection{Daidzein and biochanin A influence the cell cycle regulatory protein $\mathbf{P 5 3}$}

A significant portion of the T-47D cells became detached from the culture flasks and floated in the culture medium after treatment with high concentrations of biochanin $\mathrm{A}$ $\left(>40 \mu \mathrm{g} \cdot \mathrm{mL}^{-1}\right)$ or daidzein $\left(>80 \mu \mathrm{g} \cdot \mathrm{mL}^{-1}\right)$. 
A

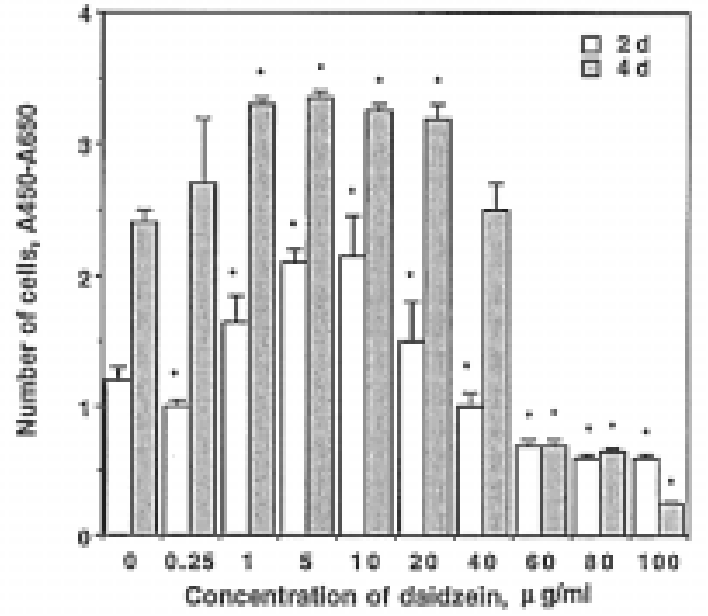

B

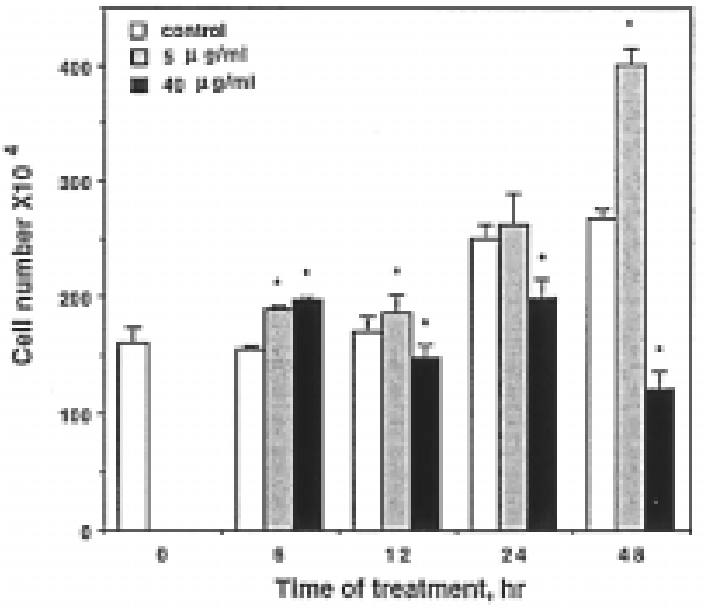

Figure 1. The growth regulatory effects of daidzein and biochanin $\mathrm{A}$ on the human breast cancer cell line T-47D The T-47D cells were treated with daidzein $(\mathbf{A}, \mathbf{B})$ or biochanin A $(\mathbf{C})$ for the indicated time. For controls, DMSO was added to the cells in parallel and incubated for the same period of time as the phytoestrogen-treated samples. The cell proliferation of each sample after individual treatment was determined as described in Materials and methods. The results are the means of triplicate determinations, and error bars represent SEM. Experiments with similar designs were performed at least twice. The * indicates significant difference $(p<0.05)$.

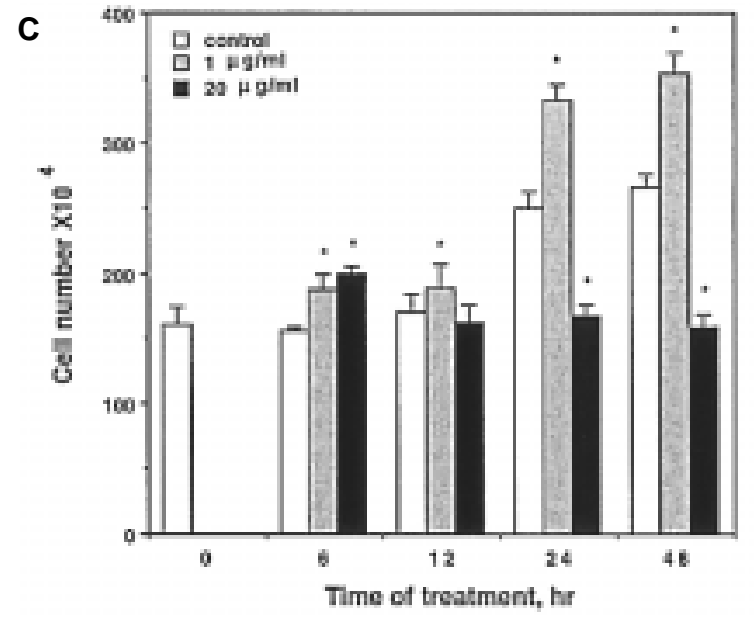



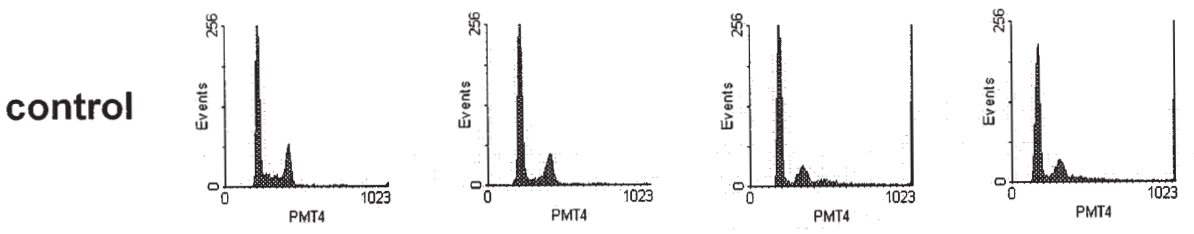

Bio-1
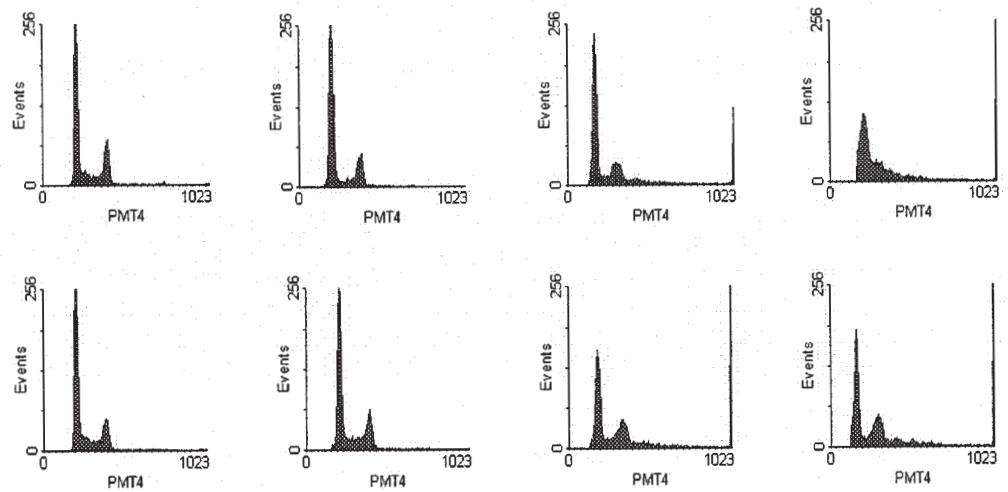

Dai-5
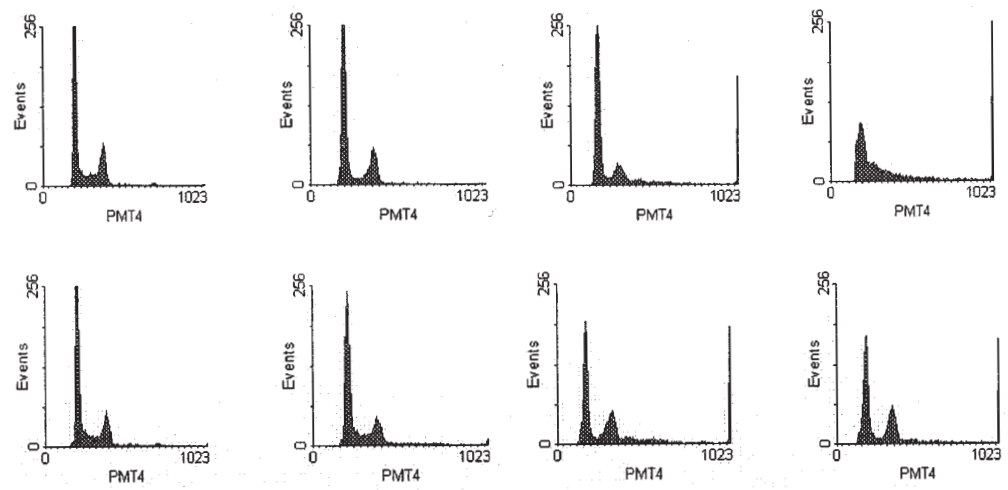

$6 \mathrm{~h}$

$12 \mathrm{~h}$

$24 \mathrm{~h}$

$48 \mathrm{~h}$

Figure 2. The effects of daidzein and biochanin A on the cell cycle progression of T-47D cells. The T-47D cells were incubated with biochanin A (bio A) at the concentration of 1 or $20 \mu \mathrm{g} \cdot \mathrm{mL}^{-1}$ or daidzein (dai) at the concentration of 5 or $40 \mu \mathrm{g} \cdot \mathrm{mL}^{-1}$ for $6-48 \mathrm{~h}$ and the percentage of cells in each cell cycle phase (G1, S and G2M) was determined by flow cytometry. Similar results were obtained in three experiments of similar design.

These cells, which were floating, appeared to consist of large percentage of non-viable cells based on the dye exclusion assays. To analyze the potential difference in the P53 protein level between the attached cells and floating cells, both types of cells were collected separately and cell lysates were prepared from each sample. The results showed that P53 levels were increased in the floating cells and reduced in the attached cells at concentrations of $40 \mu \mathrm{g} \cdot \mathrm{mL}^{-1}$ for biochanin A (Fig. 3A). Biochanin A at $1 \mu \mathrm{g} \cdot \mathrm{mL}^{-1}$ that stimulated cell growth did not appear to cause any changes in the 
Table I. Cell cycle analysis of daidzein and biochanin A treated T-47D cells.

\begin{tabular}{llcr}
\hline Treatment & \multicolumn{1}{c}{ G1 } & $\mathrm{S}$ & $\mathrm{G} 2 / \mathrm{M}$ \\
\hline $24 \mathrm{~h}$ & & & \\
$\quad$ control & $71.0(11.6)^{\mathrm{a}}$ & $5.5(31.8)$ & $23.5(78.9)$ \\
bio A (1) & $82.5(5.8)$ & $3(91)$ & $14.4(26.1)$ \\
bio A (20) & $54.6(21.4)$ & $14.1(0.2)$ & $31.2(48.2)$ \\
daidzein (5) & $65.4(13.0)$ & $9.3(13.6)$ & $25.3(61.2)$ \\
daidzein (40) & $54.7(1.1)$ & $9.7(69.8)$ & $35.7(55.4)$ \\
48 h & & & \\
control & $68.2(9.6)$ & $6.5(50)$ & $25.3(71.9)$ \\
bio A (1) & $45.8(25.6)$ & $51.8(61.2)$ & $2.4(98.3)$ \\
bio A (20) & $54.2(17.6)$ & $12.9(13.0)$ & $32.9(53.2)$ \\
daidzein (5) & $33.4(44.4)$ & $42.7(49.4)$ & $23.9(38.8)$ \\
daidzein (40) & $55.3(0.4)$ & $10.5(50.6)$ & $34.2(30.0)$ \\
\hline
\end{tabular}

${ }^{\text {a }}$ Variation in percentage.

${ }^{\mathrm{b}}$ Concentration of biochanin $\mathrm{A}$ in $\mu \mathrm{g} \cdot \mathrm{mL}^{-1}$.

${ }^{c}$ Concentration of daidzein in $\mu \mathrm{g} \cdot \mathrm{mL}^{-1}$.

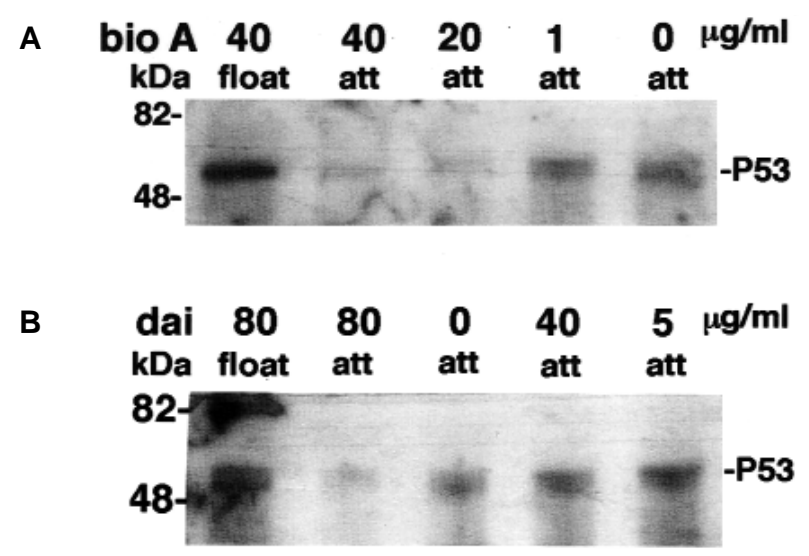

Figure 3. Protein levels of P53 in T-47D cells in response to the daidzein and biochanin A treatment. The T-47D cells were treated with biochanin A (A) or daidzein $(\mathbf{B})$ for 2 days at the concentrations indicated. Cell lysates were prepared and the levels of P53 were determined with immunoprecipitation followed by western analysis as described in the Materials and methods. Float: samples prepared from cells that became detached from the culture flask surface and were floating in the medium. att: samples prepared from cells that remained attached to the culture flask surface. 0: cells treated with DMSO in parallel at the same concentration as the treated cells. Molecular weight markers are indicated on the left.

protein level of P53. At $20 \mu \mathrm{g} \cdot \mathrm{mL}^{-1}$ of biochanin A, the growth of the T-47D cells was blocked while most of the cells still remained attached to flasks after the treatment for 2 days. The protein level of P53 in those attached cells after treatment with $20 \mu \mathrm{g} \cdot \mathrm{mL}^{-1}$ of biochanin A was lower than that of DMSO-treated control cells (Fig. 3A). A similar effect on the protein level of P53 was observed in T-47D cells 
treated with daidzein (Fig. 3B). The level of the P53 protein was greatly increased in the floating cells after treatment with $80 \mu \mathrm{g} \cdot \mathrm{mL}^{-1}$ daidzein for 2 days. At this concentration, most of the T-47D cells were detached from the culture flask and floated in the medium. In the cells treated with lower concentrations of daidzein (5 and $40 \mu \mathrm{g} \cdot \mathrm{mL}^{-1}$ ), the cells remained attached and there were no significant changes in the P53 protein level compared to the DMSO-treated control cells.

\section{DISCUSSION}

The results presented in this study support previous observations that showed that isoflavones elicit a biphasic response in the DNA synthesis $[12,35]$ and cell proliferation [30] of the estrogen receptor of positive human breast cancer cells. In addition, the effects of daidzein and biochanin A on these cells appeared to be associated with the expression level of P53. Several metabolites of biochanin A (genistein, genistein 7-sulfate, biochanin A sulfate, and hydroxylated and methylated forms of biochanin A) have been detected in T-47D cells [24]. The similar effects on cell growth between daidzein and biochanin $\mathrm{A}$ indicated that some common regulatory pathways might be involved. We previously showed that DNA synthesis was regulated by biochanin A treatment so that low concentrations of biochanin A stimulated DNA synthesis while high concentrations of biochanin $\mathrm{A}$ inhibited DNA synthesis [13]. This observation was corroborated here by the flow cytometric DNA analysis results: after $48 \mathrm{~h}$ of incubation with biochanin $\mathrm{A}$ at growth stimulatory concentration, T-47D cells showed an increase in the percentage of cells in the S-phase. Such behavior is indicative of a reduction in the period of the G1-S phase. The flavonoid quercetin is also reported to regulate the G1/S phase of the cell cycle in a similar way [33]. At growth inhibitory concentrations, however, the time course analysis suggested a more complex perturbation in cell cycle control: incubation for 6-48 h at the high concentration of biochanin A led to a slow fall in the $S$ phase. This suggests that cell cycle progression was delayed especially at the stage of the G1-S transition. The effect of daidzein on cell cycle control in T-47D cells was similar to that of biochanin A. Daidzein increased the percentage of cells in the $S$ phase at a low concentration and slowed the progression from the G2/M phase to the G1 phase at a high concentration. The concentrations used in this study as well as most other in vitro studies were higher than what has been detected in the serum $[3,12,36]$. One of the hypotheses for this observation has been that bioaccumulation and bio-concentration of these phytoestrogens might have occurred in certain tissues such as breast and bladder, respectively, resulted in a local higher concentration than the concentration found in serum. Nevertheless, the true in vivo effect of the phytoestrogens on human has to be evaluated from all possible aspects and considering all potential influential factors.

The tumor suppressor protein P53, which is commonly inactivated in tumors, is a major regulator of cell cycle progression in response to DNA damage or arrest of DNA synthesis [4, 9, 10, 17, 22]. Apoptosis has already been proposed as one of the candidate pathways by which phytoestrogen might inhibit growth because both daidzein and biochanin A have been shown to induce condensed chromosomes in MCF-7 cells as revealed by acridine orange staining [33]. Moreover, further evidence for the involvement of P53 in cell cycle arrest has been provided by Morris et al. [22], who reported that the wild type P53 protein is essential for apoptosis to be induced immediately after exposure to the phytoestrogen genistein. In our study, human breast cancer cells T-47D treated with biochanin A or daidzein showed elevated protein levels of P53. Frey and Singletary [7] also observed that genistein increases the expression of P53 by 2.8 fold in the mammary epithelial cell line. It has been proposed that the signals 
generated by the treatments lead to an increase in the level of the P53 protein and in the stimulation on its ability to activate transcription, which leads in turn to cell cycle arrest in both the $\mathrm{G} 1$ and $\mathrm{G} 2 / \mathrm{M}$ phases $[10,15,32]$. Changes in the cell-extracellular interactions were induced by high concentrations of biochanin $\mathrm{A}\left(>40 \mu \mathrm{g} \cdot \mathrm{mL}^{-1}\right)$ and daidzein ( $>80 \mu \mathrm{g} \cdot \mathrm{mL}^{-1}$ ) since the T-47D cells became detached from the culture flask surface after treatment. This interruption in cell attachment may also have induced apoptosis in the T-47D cells and resulted in the loss of viability in floating cells. Previous reports have suggested that the lack of cell adhesion may play a role in the regulation of P53 since the inhibition of the cell-matrix interactions induces both apoptosis and an increase in P53 levels [16]. A chain of events, starting with the activation of P53, and proceeding via p21(waf1/ cip1) which is one of the target genes of $\mathrm{P} 53$, to the cell cycle regulator cyclin $\mathrm{A}$, is activated in response to the loss of cellular adherence. Cells become arrested in the G1 of the cell cycle [40].

\section{CONCLUSION}

Whatever the details of the molecular mechanisms may be, the natural plant phytoestrogens biochanin A and daidzein are able to either promote or inhibit the growth of human breast cancer cells depending on their concentrations. The cell cycle regulatory proteins P53 appear to be part of this regulatory system. These results presented here thus further aid in understanding the molecular mechanisms of phytoestrogens that have been considered as innovative and promising agents in cancer therapy.

\section{ACKNOWLEDGMENTS}

This work was supported in part by grants from the National Science Council, Republic of China (89-2313-B-031-002, 88-2313-B-031-007, 88-2317-B-031-001).

\section{REFERENCES}

[1] Adlercreutz H., Bannwart C., Wahala K. Makela T., Brunow G., Hase T., Arosemena P.J., Kellis J.T., Vickery L.E., Inhibition of humanaromatase by mammalian lignans and isoflavonoid phytoestrogens, J. Steroid Biochem. Mol. Biol. 44 (1993) 147-153.

[2] Adlercreutz H., Markkanen H., Watanabe S., Plasma concentrations of phyto-oestrogens in Japanese men, Lancet 13 (1993) 1209-1210.

[3] Adlercreutz H., Goldin B.R., Gorbach S.L., Hockerstedt K.A.V., Watanabe S., Hamalainen E.K., Markkanen M.H., Makela T.H., Wahala K.T., Soybean phytoestrogen intake and cancer risk, J. Nutr. 125 (1995) 757s-770s.

[4] Agarwal M.L., Agarwal A., Taylor W.R. Chernova O., Sharma Y., Stark G.A., A p53dependent S-phase checkpoint helps to protect cells from DNA damage in response to starvation for pyrimidine nucleotides, Proc. Natl. Acad. Sci. USA 95 (1998) 14775-14780.

[5] Bradbury R.B., White D.E., Oestrogens and related substances in plants, Vitam. Horm. 12 (1954) 207-233.

[6] Eldridge A., Kwolek W.F., Soybean isoflavones: effect of environment and variety on composition, J. Agric. Food Chem. 31 (1983) 394-396.

[7] Frey R., Singletary K., Effects of genistein on cell proliferation and cell cycle arrest in nonneoplastic human mammary epithelial cells; involvement of Cdc2, p21(waf/cip1), p27, and Cdc25C expression, Biochem. Pharmacol. 61 (2001) 979-989.

[8] Fried J., Perez A.G., Clarkson B.D., Rapid hypotonic method for flow cytofluorometry of monolayer cell cultures. Some pitfalls in staining and data analysis, J. Histochem. Cytochem. 26 (1978) 921.

[9] Fu L., Minden M.D., Benchimol S., Translational regulation of human p53 gene expression, EMBO J. 15 (1996) 4392-4401.

[10] Greenblatt M.S., Bennett W.P., Hollstein M. Harris C.C., Mutations in the p53 tumor suppressor gene: clues to cancer etiology and molecular pathogenesis, Cancer Res. 54 (1994) 4855-4878.

[11] Greene L.A., Nerve growth factor prevents the death and stimulates the neuronal differentiation of clonal PC12 phenochromocytoma cells in serum-free medium, J. Cell Biol. 78 (1978) 747-755.

[12] Hsu J., Hung H., Chen C., Hsu W., Ying C., Effects of the Dietary Phytoestrogen Biochanin A on Cell Growth in the Mammary Carcinoma Cell Line MCF-7, J. Nutr. Biochem. 10 (1999) 510-517.

[13] Hsu J., Jean T., Chan M., Ying C., Differential Display Screening for Specific Gene Expression Induced by Dietary Nonsteroidal Estrogen, Mol. Reprod. Dev. 52 (1999) 141-148. 
[14] Hsu J., Hsu W.L., Ying C., Dietary phytoestrogen regulates estrogen receptor gene expression in human mammary carcinoma cells, Nutr. Res. 19 (1999) 1447-1457.

[15] Hupp T.R., Sparks A., Lane D.P., Small peptides activate the latent sequence-specific DNA binding function of p53, Cell 83 (1995) 237-245.

[16] Iwamoto H., Sakai H., Tada S., Nakamuta M. Nawata H., Induction of apoptosis in rat hepatic stellate cells by disruption of integrin-mediated cell adhesion, J. Lab. Clin. Med. 134 (1999) 83-89.

[17] Kuerbitz S.J., Plunkett B.S., Walsh W.V., Kastan M.B., Wild-type p53 is a cell cycle checkpoin determinant following irradiation, Proc. Natl. Acad. Sci. USA 89 (1992) 7491-7495.

[18] Lee A.W., Nambirajan S., Moffat J.G., CSF-1 activates MAPK-dependent and p53-independent pathways to induce growth arrest of hormone-dependent human breast cancer cells, Oncogene 18 (1999) 7477-7494.

[19] Markaverich B.M., Roberts R.R., Alejandro M.A., Johnson G.A., Middleditch B.S., Clark J.H., Bioflavonoid interaction with rat uterine type II binding sites and cell growth inhibition, J. Steroid Biochem. Mol. Biol. 30 (1988) 71-78

[20] Martin P.M., Horwitz K.B., Messina M.J., Persky V., Setchell K.D.R., Barnes S., Soy intake and cancer risk: A review of the in vitro and in vivo data, Nutr. Cancer 21 (1994) 113-131.

[21] Miksicek R., Interaction of naturally occurring nonsteroidal estrogens with expressed recombinant human estrogen receptor, J. Steroid Biochem. Mol. Biol. 49 (1994) 153-160.

[22] Morris S.M., Chen J.J., Domon O.E., Mcgarrity L.J., Bishop M.E., Manjanatha M.G., Casciano D.A., p53, mutations and apoptosis in genistein-exposed human lymphoblastoid cells, Mutat. Res. 405 (1998) 41-56.

[23] Morton M.S., Wilcox G., Wahlqvist M.L. Griffiths K., Determination of lignans and isoflavonoids in human female plasma following dietary supplementation, J. Endocrinol. 142 (1994) 51-259.

[24] Peterson G., Evaluation of the biochemical targets of genistein in tumor cells, J. Nutr. 125 (1995) 784s-770s.

[25] Peterson G., Barnes S., Genistein inhibition of the growth of human breast cancer cells: independence from estrogen receptors and the multidrug resistance gene, Biochem. Biophys. Res. Commun. 179 (1991) 661-667.

[26] Pike M.C., Spicer D.C., Dahmoush L., Press M.F., Estrogens, progestogens, normal breast cell proliferation, and breast cancer risk, Epidemiol. Rev. 15 (1993) 17-35.

[27] Prall O.W., Rogan E.M., Musgrove E.A., Watts C.K., Sutherland R.L., c-myc or cyclin D1 mimics estrogen effects on cyclin E-Cdk2 activation and cell cycle reentry, Mol. Cell Biol. 18 (1998) 4499-4508
[28] Prall O.W., Rogan E.M., Sutherland R.L., Estrogen regulation of cell cycle progression in breast cancer cells, J. Steroid Biochem. Mol. Biol. 65 (1998) 169-174.

[29] Rudkin B.B., Lazarovici P., Levi B., Abe Y., Fujita K., Guroff G., Cell cycle-specific action of nerve growth factor in PC12 cells: differentiation without proliferation, EMBO J. 8 (1989) 3319-3325.

[30] Sathyamoorthy N., Wang T.T.Y., Phang J.M., Stimulation of $\mathrm{pS} 2$ expression by diet-derived compounds, Cancer Res. 79 (1994) 957-961.

[31] Schmidt E.V., The role of c-myc in cellular growth control, Oncogene 13 (1999) 2988-2996.

[32] Schwartz D., Almog N., Peled A., Goldfinger N., Rotter V., Role of wild type p53 in the $\mathrm{G} \operatorname{sub}(2)$ phase: Regulation of the gamma-irradiation induced delay and DNA repair, Oncogene 15 (1997) 2597-2607.

[33] Spinozzi F., Pagliacci M.C., Migliorati G., Moraca R., Grignani F., Riccardi C., Nicoletti I. The natural tyrosine kinase inhibitor genistein produces cell cycle arrest and apoptosis in Jurkat T-leukemia cells, Leukemia Res. 18 (1994) 431-439.

[34] Steinmetz K., Potter J.D., in: Vegetables, fruit, and cancer. II. Mechanisms, Cancer Causes Control 2 (1991) 427-442.

[35] Thompson A.M., Steel C.M., Chetty U., Hawkins R.A., Miller W.R., Carter D.C., Forrest A.P., Evans H.J., p53 gene mRNA expression and chromosome $17 \mathrm{p}$ allele loss in breast cancer, Br. J. Cancer 61 (1990) 74-78.

[36] Wang C., Kurzer M.S., Phytoestrogen concentration determines effects on DNA synthesis in human breast cancer cells, Nutr. Cancer 28 (1997) 236-247.

[37] Wang C., Kurzer M.S., Effects of phytoestrogens on DNA synthesis in MCF-7 cells in the presence of estradiol or growth factors, Nutr. Cancer 31 (1998) 90-100.

[38] Wang T.T.Y., Sathyamoorthy N., Phang J.M., Molecular effect of genistein on estrogen receptor mediated pathways, Carcinogenesis 17 (1996) 271-275.

[39] Whitten P.L., Russell E., Naftolin F., Influence of phytoestrogen diets on estradiol action in the rat uterus, Steroids 59 (1994) 443-449.

[40] Wu R.C., Schonthal A.H., Activation of p53-pathway in response to disruption of cellmatrix interactions, J. Biol. Chem. 14 (1997) 29091-29098.

[41] Ying C., Lin D-H., Sarkar D.H., Chen T-T. Interaction between Estrogen Receptor and Pit-1 Protein is Influenced by Estrogen in Pituitary Cells, J. Steroid Biochem. Mol. Biol. 68 (1999) 145-152.

[42] Ziegler R.G., Hoover R.N., Pike M.C, Hildesheim A., Nomura A.M., West D.W., Wu A.H., Pike M.C., Lake A.J., Horn-Ross P.L. Kolonel L.N., Siiteri P.K., Fraumeni J.F. Jr., Migration patterns and breast cancer risk in Asian-American women, J. Natl. Cancer Inst. 85 (1993) 1819-1827. 